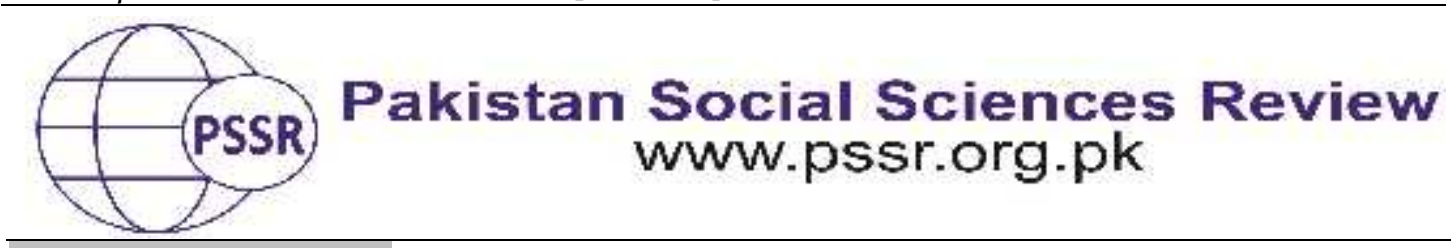

RESEARCH PAPER

\title{
Firms' Financial Constraints and Exporting Tendency in Pakistan
}

\author{
Syed Mumtaz Ali Kazmi ${ }^{1}$ Syed Muhammad Imran ${ }^{2}$ Rana Ejaz Ali Khan ${ }^{3}$
}

1. Ph.D. Scholar, Department of Economics, The Islamia University of Bahawalpur, Punjab, Pakistan

2. Visiting Lecturer, Department of Economics, The Islamia University of Bahawalpur, Pakistan

3. Professor and Chairman, Department of Economics, The Islamia University of Bahawalpur, Pakistan

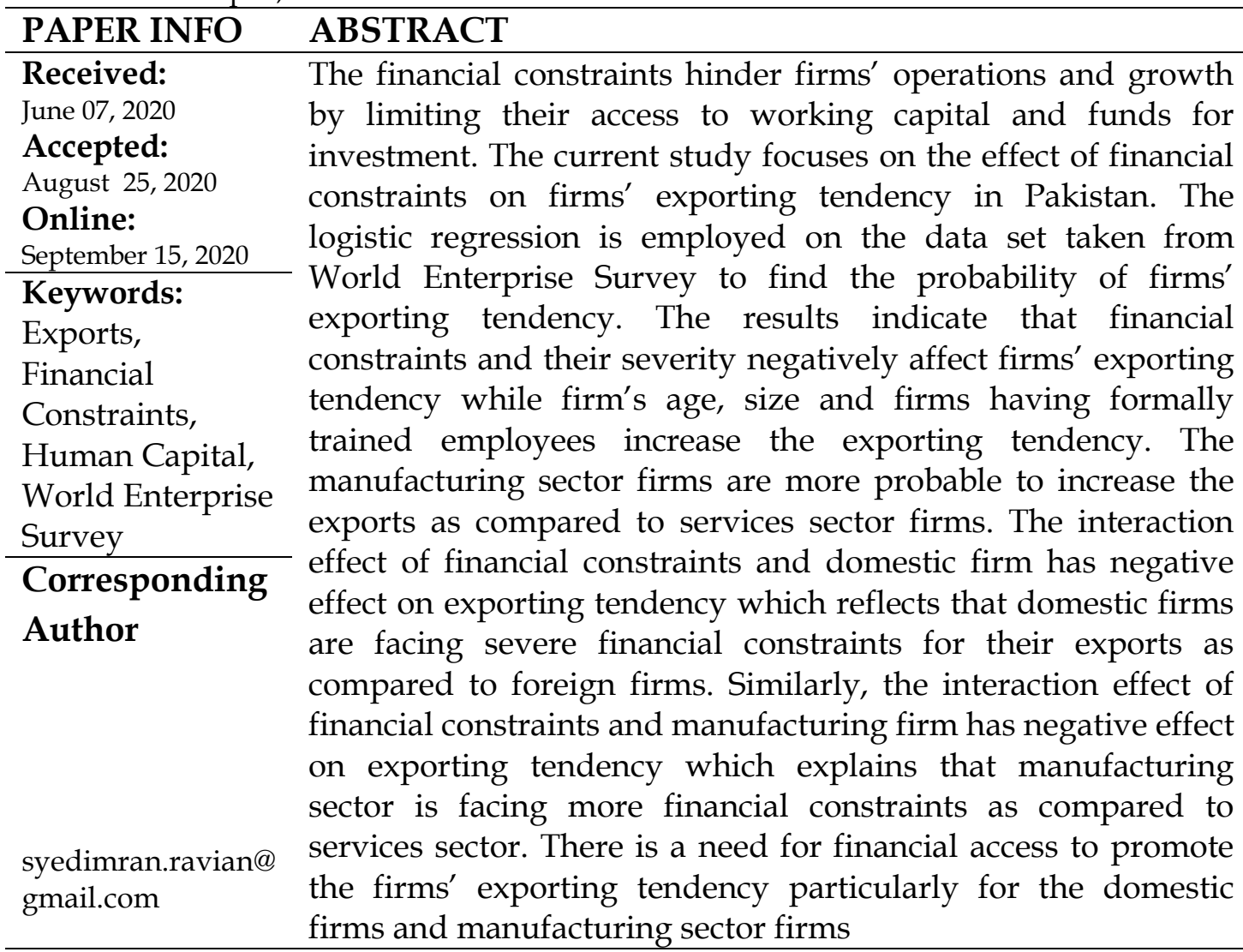

\section{Introduction}

The exports of Pakistan are relatively low as compared to South Asian nations. The export target of Pakistan for the fiscal year 2019 was set at US\$ 28 billion but it registered a decline of 0.1 percent (SBP, 2019).The literature intensely argued for the policies to promote exports considering it an engine for growth (Naghshpour, 2012). The economic efficiency and growth of the firms also depend 
upon entrance into foreign markets and exports. Higher cost of entry into foreign markets is one of the major challenges for the expansion of exports. Failure to meet the cost is probably due to financial constraints of the firms. It is particularly a severe problem in developing economies due to lack of resources.

Schumpeter (1934) pointed out that the financial market improves firm performance and the economic growth at national level. A well-developed financial system augments country's exports and economic growth (Levine, 1997). The financial access improves firm growth (Cooley \& Quadrini, 2001) and investment (Cull \& Xu, 2005).Chaney (2016) argued that the export behavior of the firms depends upon the availability of finances. The financial constraint at the firm level is a severe obstacle for the development of the firm (Beck, Demirgüç-Kunt, \& Maksimovic, 2005).

A weak financial system results into severe effect on exports and it can be a severe obstacle to firms' performance and economic growth (Alfaro \& Chen, 2012; Antras, Desai, \& Foley, 2009; Chor \& Manova, 2012; Manova, 2012; Manova, Wei, \& Zhang, 2015;Muûls, 2015). A larger part of the literature has analyzed this issue for the developed economies (Bricongne, Fontagné, Gaulier, Taglioni, \& Vicard, 2012; Cull \& Xu, 2005; Kim, 2019; Minetti \& Zhu, 2011; Svaleryd \& Vlachos, 2005). For developing economies the studies have also shown a connection between financial health and exports(Beck, Demirgüç-Kunt, \& Maksimovic, 2005; Chaney 2016; Muûls, 2015).However, the literature lacked to probe the effect of financial constraints on export in the case of Pakistan. The financial constraints alternatively the inefficient and weak financial system may have an adverse effect on exports of Pakistani firms. The issue is not previously analyzed intensively by using the national level data of firms.

The current study is an attempt to empirically test the impact of financial constraints on firm's exports in Pakistan. It distinguishes from the previous studies as itis based on a direct measure of financial constraints obtained from the World Enterprise Survey rather than measures derived indirectly from financial statements. In this way it is a contribution to the existing literature on financial constraints and export performance.

\section{Literature Review}

A variety of literature exists on the firm's financial constraints and output dimensions like the growth, investment, innovation, employment and exports. In the earlier studies, Stiglitz and Weiss (1981) documented the importance of financial constraints for firm's growth in their pioneering work. Fazzari, Hubbard, and Petersen (1988) found that financial constraints deteriorate firms' investment. Bernanke and Gertler (1990) demonstrated that financial constraints depress firms' investment and growth. Later on, Das et al. (2007) found that the average cost of entry into the foreign market is 0.34 million U.S. dollars for a firm in Colombia. Most of the firms in less developing countries cannot pay such a high cost due to 
financial constraints. In emerging economies the firms sale out lower ratio of their exports in foreign markets due to financial constraints (Berman \& Héricourt, 2010). Antras et al. (2009) developed a model for American multinational firms using annual survey data from Bureau of Economic Analysis and found that financial constraints affect the firms' cross border operations, investment and exports decisions in USA. Minetti and Zhu (2011) used survey data of Italian firms and found that credit constraint is an obstacle for the growth of high-tech industries. Recently, Muûls (2015) used trade transaction and balance sheet data of Belgian to analyze the impact of credit constraint on trading behavior. They found that more credit constraint firms are less likely to export. Chaney (2016) utilized a model of financial constraints and international trade of Melitz (2003) to show how liquidity affect the behavior of exporters in Chile. The results showed that financial constraint is the primary determinant of exports. Even if firms are specialized in production and have surplus output, lack of sufficient liquidity prevent them from exporting the output. Kim (2019) investigated that how exports respond to financial constraints in the aftermath of financial crisis in South Korea. The study utilized the unbalanced panel of manufacturing firms using survey data from business statistics. Kim estimated three equations; firstly the effect of financial constraints on exports, secondly the separate analysis of domestic and foreign firms for the same effect, and thirdly the incorporated effect of corporate ownership structure in the first equation. The results revealed that financial constraints adversely affect exports of domestic firms. During the global financial crisis effect of financial constraints on exports was larger as compared to non-crisis years. The effect of financial constraints on exports of multinational corporations was insignificant. The literature has increasingly recognized the role of financial markets in firms' international orientation and stressed that exports are particularly vulnerable to credit imperfections, however the work on financial constraints and exporting tendency of Pakistani firms is lacking, that is the gap to be filled by the current study.

\section{Material and Methods}

To estimate the impact of financial constraints on firms' exporting tendency following econometric model is framed.

$$
\mathrm{EXPORT}=\alpha+\pi_{1} \mathrm{FC}+\pi_{2} \mathrm{DOM}+\pi_{3} \mathrm{FAGE}+\pi_{4} \mathrm{FSIZE}+\pi_{4} \mathrm{HCAP}+\pi_{6} \mathrm{SEC}+e_{\bar{\imath}} \ldots . .1
$$

Where, EXPORT = exporting tendency of the firm, $\mathrm{FC}=$ financial constraints, DOM =domestic firm, FAGE =age of the firm, FSIZE =size of the firm, $\mathrm{HCAP}=$ human capital and SEC=sector of the firm (only two sectors, i.e. services and manufacturing are included in analysis while ignoring the agriculture sector due to lack of data).The same type of specification was utilized by Kim (2019) to estimate the effect of financial constraints on exports during financial crises in Korea. In the current analysis the exporting tendency of firms is included as a binary variable and defined as one if the firm is directly exporting at least50 percent of its sales, otherwise zero. The operational definitions of the remaining variables 
are shown in table 1. Keeping in view the heterogeneity in firm's size, ownership and sectors, this paper has incorporated three interaction terms and formulated Equation 2.

$$
\begin{gathered}
\text { EXPORT }=\beta+\beta_{1} \mathrm{FC}+\beta_{2} \text { DOM }+\beta_{3} \text { FAGE }+\beta_{4} \text { FSIZE }+\beta_{5} \text { HCAP }+\beta_{6} \text { SEC } \\
\beta_{7} \text { FC. SIZE }+\beta_{8} \text { FC. DOM }+\beta_{9} \text { FC. SEC }+e_{i} \quad \ldots \ldots \ldots \ldots \ldots . .2
\end{gathered}
$$

Where, FC.SIZE is interaction term of financial constraints and firm size, FC.DOM is interaction term of financial constraints and domestic firm, FC.SEC is interaction term of financial constraints and firms sector (manufacturing). The likelihood of firms' exporting tendency can be shown in logit specification in Equation 3.

$$
L_{i}=\operatorname{Ln}\left(\frac{P_{i}}{1-P_{i}}\right)=\beta_{0}+\beta_{1} F C+\beta_{2} X_{i}+u_{i}
$$

Where, $P_{i}=1$ is the probability of exporting tendency. FC is a core variable and $X_{i}$ is the vector of control variables that includes firm-specific characteristics such as domestic firm, age of the firm, size of the firm, human capital and sector of the firm. The literature evidenced that well-developed financial system augments country's exports and economic growth (Levine, 1997). Financial constraints negatively impact firms' exports (Beck, Demirgüç-Kunt, \& Maksimovic, 2005; Berman \& Héricourt, 2010). It is hypothesized that financial constraints (FC) have a negative effect on firms' exporting tendency in Pakistan. Firms' specific control variables like age of the firm (FAGE), size of the firm (FSIZE), and human capital (HCAP) are assumed to have a positive impact on firms' exporting tendency, while domestic firm (DOM) and sector of the firm (SEC) may have a positive or negative effect on exporting tendency of the firm.

\begin{tabular}{|c|c|c|c|}
\hline Variables & Unit of Analysis & & Definitions \\
\hline \multirow{5}{*}{$\begin{array}{l}\text { FC (Financial } \\
\text { constraints) }\end{array}$} & No constraints & $=0$ & \multirow{5}{*}{$\begin{array}{c}\text { Firm facing financial } \\
\text { constraints for growth of its } \\
\text { business. }\end{array}$} \\
\hline & Minor constraints & $=1$ & \\
\hline & Moderate constraints & $=2$ & \\
\hline & Major constraints & $=3$ & \\
\hline & Very severe constraints & $=4$ & \\
\hline $\begin{array}{l}\text { DOM (Domestic } \\
\text { firm) }\end{array}$ & \multicolumn{2}{|l|}{$\begin{array}{c}\text { Domestically owned }=1 \\
\text { Otherwise }=0\end{array}$} & $\begin{array}{c}\text { Firm that has at least } 50 \% \\
\text { ownership by domestic } \\
\text { individuals, companies or } \\
\text { organizations. }\end{array}$ \\
\hline $\begin{array}{l}\text { FAGE (Age of the } \\
\text { firm) }\end{array}$ & \multicolumn{2}{|l|}{ In years } & $\begin{array}{l}\text { The years since the } \\
\text { establishment begin operations } \\
\text { in the country. }\end{array}$ \\
\hline FSIZE (Size of the & \multicolumn{2}{|l|}{ Small firm $=0$} & The size of the firm is defined \\
\hline
\end{tabular}

Table 1

Operational Definitions of Explanatory Variables 


\begin{tabular}{|c|c|c|}
\hline firm) & $\begin{array}{ll}\text { Medium } & =1 \\
\text { Large } & =2\end{array}$ & $\begin{array}{l}\text { by "the number of permanent } \\
\text { workers". Firm with workers } \\
\text { greater than } 5 \text { but less than } 19 \\
\text { is small firm, greater than } 20 \\
\text { but less than } 99 \text { is medium } \\
\text { firm and that with greater than } \\
100 \text { is larger firm. }\end{array}$ \\
\hline $\begin{array}{l}\text { HCAP (Human } \\
\text { capital) }\end{array}$ & $\begin{array}{c}\text { If workers are trained }=1 \text {, } \\
\text { otherwise }=0\end{array}$ & $\begin{array}{c}\text { The establishment has formal } \\
\text { training programs for its } \\
\text { permanent, full-time } \\
\text { employees }\end{array}$ \\
\hline \multirow{2}{*}{$\begin{array}{l}\text { SEC (Sector of the } \\
\text { firm) }\end{array}$} & Manufacturing=1 & Firm is working in \\
\hline & Services $\quad=0$ & $\begin{array}{l}\text { manufacturing or services } \\
\text { sector. }\end{array}$ \\
\hline $\begin{array}{l}\text { FC.SIZE (Financial } \\
\text { constraints*Size of } \\
\text { the firm) }\end{array}$ & $\begin{array}{l}\text { Financial constraints } \\
\text { and small firm }=1 \\
\text { Otherwise }=0\end{array}$ & $\begin{array}{l}\text { Interaction term of financial } \\
\text { constraints and firm size }\end{array}$ \\
\hline $\begin{array}{l}\text { FC.DOM (Financial } \\
\text { constraints* } \\
\text { Domestic firm) }\end{array}$ & $\begin{array}{l}\text { Financial constraints } \\
\text { and domestic firm }=1 \\
\text { Otherwise }=0\end{array}$ & $\begin{array}{l}\text { Interaction term of financial } \\
\text { constraints and domestic firm }\end{array}$ \\
\hline $\begin{array}{l}\text { FC.SEC (Financial } \\
\text { constraints* } \\
\text { Manufacturing } \\
\text { firm) }\end{array}$ & $\begin{array}{c}\text { Financial constraints } \\
\text { and manufacturing firm }=1 \\
\text { Otherwise }=0\end{array}$ & $\begin{array}{c}\text { Interaction term of financial } \\
\text { constraints and manufacturing } \\
\text { firm. }\end{array}$ \\
\hline
\end{tabular}

The study utilized the World Bank Enterprise Survey data of 1247 Pakistani firms conducted by the World Bank (2013). After screening for missing values, the study finally regressed the model with 920 observations.

\section{Empirical Results}

Table 2 provides the descriptive statistics of the variables used in the empirical analysis.

Table 2

Descriptive Statistics

\begin{tabular}{cccccc}
\hline Variable & Observation & Mean & Std. Dev. & Min & Max \\
\hline EXPORT & 1,247 & 0.21251 & 0.4092479 & 0 & 1 \\
\hline FC & 1,238 & 1.378029 & 1.252026 & 0 & 4 \\
\hline FAGE & 1,125 & 22.55111 & 13.74055 & 2 & 77 \\
\hline FSIZE & 1,002 & 0.4031936 & 0.6186494 & 0 & 2 \\
\hline DOM & 1,244 & 0.9405145 & 0.2366263 & 0 & 1 \\
\hline HCAP & 1,177 & 0.2531861 & 0.4350215 & 0 & 1 \\
\hline SEC & 1,247 & 0.8356055 & 0.3707819 & 0 & 1 \\
\hline
\end{tabular}


Table 3 shows the correlation between the variables. It shows negative relationship between financial constraints and firms' exporting tendency.

Table 3

Correlation Matrix

\begin{tabular}{llllllll}
\hline & EXPORT & FC & FAGE & FSIZE & DOM & HCAP & SEC \\
\hline EXPORT & 1.0000 & & & & & & \\
\hline FC & -0.0937 & 1.0000 & & & & & \\
\hline FAGE & 0.0953 & -0.1057 & 1.0000 & & & & \\
\hline FSIZE & 0.1948 & -0.0633 & 0.0911 & 1.0000 & & & \\
\hline DOM & -0.1807 & 0.0925 & -0.0470 & -0.0388 & 1.0000 & & \\
\hline HCAP & 0.1454 & -0.0716 & 0.0612 & 0.2312 & -0.0866 & 1.0000 & \\
\hline SEC & 0.0184 & 0.0627 & 0.0311 & 0.0047 & 0.0204 & -0.2096 & 1.0000 \\
\hline
\end{tabular}

Table 4 shows the results of the logistic regression model for two specifications. In the first specification, the financial constraints is measured by categorical variable as mention in Table 1 and in the second specification it is measured by a binary variables categorized as zero for no constraints and one for any level of constraints. Furthermore, in the second specification the interaction term of financial constraints with firm size, domestic firm and manufacturing firm are included.

Table 4

Result of the Logistic Regression Model

\begin{tabular}{ccc}
\hline Variables & Specification (1) & Specification (2) \\
\cline { 1 - 2 } FC (Financial constraints) & & \\
No constraints = Reference category & -.1572785 & \\
Moderate & $(.1984727)$ & $-1.308172^{*}$ \\
& {$[0.201]$} & $(.3018664)$ \\
Severe & $-.5799867^{* *}$ & {$[0.048]$} \\
& $(.3095147)$ & \\
\hline & {$[0.054]$} & \\
\hline FAGE (Age of the firm) & $.0117714^{*}$ & $.0120995^{*}$ \\
& $(.0059725)$ & $(.0058874)$ \\
FSIZE (Size of the firm) & {$[0.000]$} & {$[0.007]$} \\
\hline Small firm = Reference category & & \\
Medium size & $.8680341^{*}$ & $1.006007^{*}$ \\
& $(.1846163)$ & $(.3144474)$ \\
Large size & {$[0.003]$} & {$[0.000]$} \\
\hline & $2.382223^{*}$ & $1.745305^{*}$ \\
& $(.4466963)$ & $(.358678)$ \\
& {$[0.002]$} & {$[0.001]$} \\
\hline
\end{tabular}




\begin{tabular}{|c|c|c|}
\hline DOM (Domestic firm) & $\begin{array}{c}-1.367554^{*} \\
(.298829) \\
{[0.004]}\end{array}$ & $\begin{array}{c}-1.606837^{*} \\
(.4965587) \\
{[0.008]}\end{array}$ \\
\hline HCAP (Human capital) & $\begin{array}{c}.5569291^{*} \\
(.2044329) \\
{[0.006]}\end{array}$ & $\begin{array}{c}.5583877^{*} \\
(.2056778) \\
{[0.005]}\end{array}$ \\
\hline \multicolumn{3}{|l|}{$\begin{array}{l}\text { SEC (Sector of the firm) } \\
\text { Service sector }=\text { Referencecategory }\end{array}$} \\
\hline Manufacturing firms & $\begin{array}{c}.3209513^{*} \\
(.2807032) \\
{[0.002]}\end{array}$ & $\begin{array}{c}1.024622^{*} \\
(.4631841) \\
{[0.001]}\end{array}$ \\
\hline $\begin{array}{l}\text { FC.FSIZE (Financial constraints*Size of } \\
\text { the firm) }\end{array}$ & & $\begin{array}{c}.2463852 \\
(.3869454) \\
{[0.299]}\end{array}$ \\
\hline $\begin{array}{c}\text { FC.DOM (Financial } \\
\text { constraints*Domestic firm) }\end{array}$ & & $\begin{array}{c}-.3606209^{*} \\
(.1730108) \\
{[0.006]}\end{array}$ \\
\hline $\begin{array}{c}\text { FC.SEC (Financial } \\
\text { constraints*Manufacturing firm) }\end{array}$ & & $\begin{array}{c}-1.121817^{*} \\
(.558917) \\
{[0.001]}\end{array}$ \\
\hline Constant & $\begin{array}{c}-1.184567^{*} \\
(.4113059) \\
{[0.004]}\end{array}$ & $\begin{array}{c}-1.645828^{*} \\
(.6087704) \\
{[0.002]}\end{array}$ \\
\hline Number of observations & 920 & 920 \\
\hline Wald Chi & 71.32 & 60.11 \\
\hline Prob & 0.000 & 0.0000 \\
\hline
\end{tabular}

Note: *and ${ }^{* *}$ indicate level of significance at 5 and10 percent, respectively. Robust standard error is shown in single parenthesis and probability value is shown in brackets.

The results in Table 4 show that financial constraints have a negative impact on the firm's exporting tendency in specification 1(without interaction term) and specification 2 (with interaction terms), which indicate that the likelihood of firms' exporting tendency declines as a result of financial constraints. This result is in line with the findings of Beck et al. (2005) for 51 developing countries and Cooley and Quadrini (2001) for USA. In specification 1, for the firms that consider financial constraints as severe obstacles for their business, the exporting tendency is inversely affected by financial constraints; however, the results are statistically insignificant for the firms which consider financial constraints as moderate obstacles. It clearly explains that the financial constraints as well as the level of financial constraints hinder the exporting tendency of Pakistani firms. The results are consistent with the finding of Greenaway, Guariglia and Kneller (2007) and Berman and Héricourt (2010) for emerging and developing nations. The results may be explained on the fact that in order to penetrate into foreign markets the firms have to bear sunk cost 
that leads to increased financial constraints and results into decreased exporting tendency.

Theoretically the older firms are assumed export oriented firms. The results in both specifications 1 and 2 indicate increasing probability of firms' age on exporting tendency, which expresses that by increase in firm's age the firms are more likely to increase their exports. It is supported by the existing literature (Manova, 2012).As concerned the firm's size the results in specification 1 and 2 indicate a positive impact of firm's size on exporting tendency of the firm. In both specifications the results indicate that the probability of the exporting tendency of the large firms is greater than medium size firms. The findings are supported by the existing literature (Manova, 2012).The results in specification 1 and 2 indicate negative impact of domestic firms on exporting tendency of the firm, which shows that the likelihood of exporting tendency of the domestic firm is lower as compared to foreign counterparts. It was hypothesized that human capital absorbed by the firm in the form of formal training of the employees has a positive effect on exporting tendency. The results in both specifications indicate that human capital increases the probability of exporting tendency of firms in Pakistan. It may explain that firms which spend more on skills and training of their employees are more export oriented. The results in both specifications indicate increasing probability of manufacturing sector on exporting tendency. In specification 2 the results of interaction terms of financial constraints and domestic firm expresses the decreasing probability of exporting tendency if the domestic firms is facing financial constraints. It may be inferred that domestic firms are severely affected by the financial constraint as compared to foreign firms. It is direly related with policy implications that are to enhance the exports domestic firms needed to be financed. Similarly, the interaction effect of financial constraints and manufacturing firm has also shown negative probability for exporting tendency. It further explains that manufacturing firms need priority in financing for the exports.

Table 5

Marginal Effects of Logistic Regression Model (Specification 1)

\begin{tabular}{ccccc}
\hline & $\mathrm{d} Y / \mathrm{dX}$ & $\begin{array}{c}\text { Delta-Method } \\
\text { Std. Err. }\end{array}$ & $\begin{array}{c}\text { Z- } \\
\text { Statistics }\end{array}$ & Probability \\
\hline FC (Financial constraints) & -.0189277 & .0109002 & -1.74 & 0.082 \\
\hline FAGE (Age of the firm) & .0015065 & .0007918 & 1.90 & 0.057 \\
\hline FSIZE (Size of the firm) & .0791265 & .0173887 & 4.55 & 0.000 \\
\hline DOM (Domestic firm) & -.1749073 & .0388237 & -4.51 & 0.000 \\
\hline HCAP (Human capital) & .076258 & .0268 & 2.85 & 0.004 \\
\hline SEC(Here Manufacturing $=1$ ) & .0482805 & .0373791 & 1.29 & 0.196 \\
\hline Note: *and** indicate level of significant at 5and 10 percent, respectively.
\end{tabular}

Table 5 provides the results of the marginal effect of the logistic regression model for specification 1 . The results revealed that exporting tendency of the firm declines by 1.89 percent as an incremental change in financial constraints. It means if a firm moves from no constraints to moderate constraints or from moderate to 
severe constraints the exporting tendency of that firm will decrease by 1.89 percent. The results of marginal effects have shown positive impact of firm age and size on exporting tendency of the firm. It explains that one additional year of firm's age increases the exporting tendency by 0.15 percent and jumping of the firm from small to medium and from medium to large size increases the exporting tendency of the firm by 7.91 percent. The results of marginal effects have shown negative impact of domestic firms on exporting tendency of the firm. The exporting tendency of the firms declines by 17.49 percent when the firm moves from foreign firm to domestic firm. The results further revealed that exporting tendency of the firm increases by 7.62 percent by increasing human capital through providing formal training programs to full time employees. The results of marginal effects have shown positive impact of manufacturing sector on exporting tendency of the firm. It explains that exporting tendency of the firm increases by 4.82 percent by switching from services sector to manufacturing sector firms.

\section{Conclusion and Policy Recommendation}

The objective of the current study was to estimate the effect of financial constraints on firms' exporting tendency in Pakistan. We have applied logistic regression on World Enterprise Survey dataset to find the probability of firms' exporting tendency. The study concluded that financial constraints decrease the likelihood of exporting tendency. The firms facing the severe financial constraints have less probability of exporting tendency as compared to those facing no financial constraints. Firm-specific characteristics such as age of the firm, size of the firm and human capital increases the probability of firms' exporting tendency. Foreign firms have high probability for exporting tendency as compared to domestic firms. The domestic firms facing the financial constraints have lower probability of export tendency as compared to foreign firms facing the same issue. It has strong policy implications, i.e. domestic firms should be financed to increase their exports particularly. The firms working in manufacturing sector also have high probability of exporting tendency.

On the other hand manufacturing firms facing the financial constraints are less likely to increase the export the exports as compared to the services sector firms facing the financial constraints. From the policy perspective it is pertinent to mention that manufacturing sector direly needs financing access for export tendency as it is the sector which has higher probability for export tendency as well it has severe negative effect of financing on export tendency.

The results have further policy implications, i.e. there is a general need for financial access to promote firms' exports. The financial sector should be developed for provision of easy access to finance forthe firms so that firms can increase their exporting tendency. The skill and training facilities to the employees by the firms or through public sector vocational and management training may boost the exporting tendency. 


\section{References}

Alfaro, L., \& Chen, M. X. (2012). Surviving the global financial crisis: foreign ownership and establishment performance. American Economic Journal: Economic Policy, 4(3), 30-55.

Antras, P., Desai, M. A., \& Foley, C. F. (2009). Multinational firms, FDI flows, and imperfect capital markets. The Quarterly Journal of Economics, 124(3), 1171-1219.

Beck, T., Demirgüç-Kunt, A., \& Maksimovic, V. (2005). Financial and Legal Constraints to Growth: Does Firm Size Matter? The Journal of Finance, 60(1), 137177.

Berman, N., \& Héricourt, J. (2010). Financial factors and the margins of trade: Evidence from cross-country firm-level data. Journal of Development Economics, 93(2), 206-217.

Bernanke, B., \& Gertler, M. (1990). Financial fragility and economic performance. The Quarterly Journal of Economics, 105(1), 87-114.

Bricongne, J.-C., Fontagné, L., Gaulier, G., Taglioni, D., \& Vicard, V. (2012). Firms and the global crisis: French exports in the turmoil. Journal of International Economics, 87(1), 134-146.

Chaney, T. (2016). Liquidity constrained exporters. Journal of Economic Dynamics and Control, 72, 141-154.

Chor, D., \& Manova, K. (2012). Off the cliff and back? Credit conditions and international trade during the global financial crisis. Journal of International Economics, 87(1), 117-133.

Cooley, T. F., \& Quadrini, V. (2001). Financial markets and firm dynamics. American Economic Review, 91(5), 1286-1310.

Cull, R., \& Xu, L. C. (2005). Institutions, ownership, and finance: the determinants of profit reinvestment among Chinese firms. Journal of Financial Economics, 77(1), 117-146.

Das, S., Roberts, M. J., \& Tybout, J. R. (2007). Market entry costs, producer heterogeneity, and export dynamics. Econometrica, 75(3), 837-873.

Kim, M. (2019). Effects of financial constraints on export performance of firms during the global financial crisis: microeconomic evidence from Korea. Applied Economics Letters, 26(1), 10-15.

Levine, R. (1997). Financial development and economic growth: views and agenda. Journal of Economic Literature, 35(2),740-776. 
Manova, K. (2012). Credit constraints, heterogeneous firms, and international trade. Review of Economic Studies, 80(2), 711-744.

Manova, K., Wei, S.-J., \& Zhang, Z. (2015). Firm exports and multinational activity under credit constraints. Review of Economics and Statistics, 97(3), 574-588.

Melitz, M. (2003). The impact of trade on aggregate industry productivity and intraindustry reallocations. Econometrica, 71(6), 1695-1725.

Minetti, R., \& Zhu, S. C. (2011). Credit constraints and firm export: Microeconomic evidence from Italy. Journal of International Economics, 83(2), 109-125.

Muûls, M. (2015). Exporters, importers and credit constraints. Journal of International Economics, 95(2), 333-343.

Naghshpour, S. (2012). Are exports an engine of growth? International Journal of Trade and Global Markets, 5(2), 153-166.

Schumpeter, J. (1934). The theory of economic development. MA: Harvard University Press.

SBP (2019) Annual Report 2018-2019. State Bank of Pakistan (SBP). Available at http:// www.sbp.org.pkAccessed on January 10, 2019.

Svaleryd, H., \& Vlachos, J. (2005). Financial markets, the pattern of industrial specialization and comparative advantage: Evidence from OECD countries. European Economic Review, 49(1), 113-144.

World Bank (2013) Enterprise Survey. Available at https://www.enterprisesurveys.org. Accessed on January 10, 2020. 